\title{
A Seven (or so) Year Hitch: How Has The Coalition's Pledge To Restore The Right To Non-Violent Protest Fared?
}

In the course of the 2010 election campaign, the Liberal Democrats committed themselves to "restore the right to protest by reforming the Public Order Act to safeguard non-violent protest even if it offends; and restrict the scope of injunctions issued by vested interests." ${ }^{1}$ This led, after the formation of the Coalition government in May 2010, to a pledge to "restore rights to non-violent protest". ${ }^{2}$ Nearly a decade on, it is time to assess how far that was brought into effect. This article takes a broad sweep across the past eight years, looking at peaceful protest and political participation. It concludes that, with some honourable exceptions, the trend has been a regressive one or at least not a liberalising one. That is probably unsurprising. While there have been some advances at doctrinal level, the practical reality on the streets for those wishing to express their dissent or bring about political/social change is one marked by increasing difficulty. The article is in two main parts. The first, shorter part plots some of the key events in the period. The second is organised around four themes, each illustrating a tension or an area of interplay between protesters and the state ${ }^{3}$ : doctrinal developments; policing practice; non-state - that is private - involvement and regulation; and access to civic space. ${ }^{4}$

\footnotetext{
${ }^{1}$ Liberal Democrat Manifesto 2010 p. 93

${ }^{2}$ The Coalition: Our Programme for Government p.11 available here https://www.gov.uk/government/publications/the-coalition-documentation (access on 19 December 2017). ${ }^{3}$ It is by no means a compendious or encyclopaedic account, but one that is selective and illustrative of the eight-year period in its entirety.

${ }^{4}$ It takes no account of changes to the law regulating industrial protests such as the Trade Union Act 2016.
} 


\section{EVENTS $2010-2017$}

The coming into being of the Coalition in 2010 was a response to what was perceived as the financial mishandling of the British economy by Gordon Brown, first as Chancellor for ten years and then, from 2007, as Prime Minister, dealing with the global crash in 2008. The terrain of the 2010 election campaign was fiscal responsibility and deficit reduction, the difference between the two main parties was largely the speed of reduction, and thus how far the reins on the public finances needed tightening.

Thus both the Coalition's raison d'être and its modus operandi were the very things likely to generate hostility and opposition - from those at the sharp end of the benefit cuts implied by its austerity package to those fearful of ideological attacks more widely on public sector provision. ${ }^{5}$ Indeed, empirical research undertaken by David Bailey "suggests that 2015 actually had the highest level of visible dissent in the UK since before the 1980s." ${ }^{6}$ This came about very quickly after the formation of the Coalition. Student demonstrations in late 2010 (at the time of

\footnotetext{
${ }^{5}$ We might simply note in passing the increased propensity to litigate the legality - generally in human rights terms - of the changes introduced to the welfare system: see e.g. $R$ (oao Carmichael) $v$ Secretary of State for Work and Pensions [2016] UKSC 58.

${ }^{6}$ D Bailey "Hard Evidence: this is the Age of Dissent - and there's much more to come" The Conversation 11 January 2016 https://theconversation.com/hard-evidence-this-is-the-age-of-dissent-and-theres-muchmore-to-come-52871 (access on 19 December 2017), building on D Bailey “Contending the crisis: What role for extra-parliamentary British politics?" (2014) 9 British Politics 68.
} 
parliamentary debates on trebling student fees, against which the LibDems had been campaigning not six months before) and mass TUC-led marches and rallies in early 2011, ran alongside the start of more direct forms of action, such as UK Uncut (highlighting tax avoidance by companies such as Vodaphone) at a time when we "were all in it together", ${ }^{7}$ and the Occupy movement. A few months later, the wedding of Prince William and Kate Middleton prompted protests, in part at the cost to the public purse in such times, as did, in 2013 (and for other reasons of course), the death of Margaret Thatcher where several hundred turned their backs as the funeral cortege made its way along the Embankment.

It is not just fiscal policy that generated such turbulence, either here or abroad. There have been large-scale demonstrations - both for and against - Scottish independence, during the referendum campaign in 2014, as well as more recently and (perhaps) more divisively across the UK during the Brexit referendum, and in its aftermath. The election of Donald Trump as $45^{\text {th }}$ President of the US in November 2016 - given some of his comments during the campaign - led to widespread protests across the world, concerned about what this said about the treatment of women. An estimated 100,000 marched in central London on his first day in office, in January 2017, as well as in other UK cities such as Belfast, Cardiff, Edinburgh, Lancaster, Leeds, Liverpool, Manchester and Bristol. ${ }^{8}$ In

\footnotetext{
7 Emblazoned on p.vi of the Conservative's 2010 manifesto: "Invitation to join the Government of Britain".

${ }^{8}$ A march of 100,000 announced by UKIP leader Nigel Farage in London, planned for the day the Supreme Court was due to hand down judgment in Miller in December 2016 was cancelled for fear of hijacking by right wing extremists: J Watts, "Nigel Farage's Brexit march on Supreme Court cancelled amid claims it might be hijacked by far right groups" The Independent 25 November 2016 http://www.independent.co.uk/news/uk/politics/nigel-farage-brexit-march-cancelled-supreme-court-farright-article-50-a7439246.html (access on 19 December 2017).
} 
the summer of 2016, to mark five years after the shooting of Mark Duggan in Tottenham (and the UK-wide riots that ensued, prompted in part by an escalated response by the police to a protest by his family outside the local police station), the group Black Lives Matter held sit down road protests, blocking access to both Heathrow and Birmingham airports to signify the "everyday constant disruption" in the lives of black people ${ }^{9}$, and also to bring attention to the use of the airports for deportation. In late 2017, came the \#MeToo movement. This was prompted initially by the making public of allegations of sexual assaults and harassment in Hollywood, but within a few weeks had grown to a global campaign encompass sexual harassment at work more widely, and more widely the treatment of women. It has generally been a social media, viral campaign with thousands using the \#MeToo to bear witness, and voice their opposition, and this has very much been the case in the UK, though it has taken a more physical form too as this march in Bristol shows. ${ }^{10}$

Our concern should not simply be staged large-scale protest events. For too long, the focus of policy makers and academics has been on such. I have written about this elsewhere, but protest as socio-political activity

\footnotetext{
9 BBC News "Black Lives Matter protests stop cars and trams across England", 5 August 2016 http://www.bbc.co.uk/news/uk-england-nottinghamshire-36983852 (access on 19 December 2017). Those at Heathrow were found guilty of wilfully obstructing the highway (s.137 Highways Act 1980) but given conditional discharges: Press Association "Nine Black Lives Matter protesters guilty over Heathrow disruption" The Guardian 19 January 2017 https://www.theguardian.com/uk-news/2017/jan/19/nine-blacklives-matter-protesters-guilty-over-heathrow-disruption (access on 19 December 2017) and Press Association "Heathrow runway activists face no penalty over motorway protest" The Guardian 16 December 2016 (access on 19 December 2017)

https://www.theguardian.com/uk-news/2016/dec/22/heathrow-runway-activists-face-no-penalty-overmotorway-protest

${ }^{10}$ Bristol Evening Post "\#MeToo Protesters block traffic in Bristol city centre", 27 October 2017, http://www.bristolpost.co.uk/news/bristol-news/gallery/metoo-protesters-block-traffic-bristol-693792 (access on 10 January 2018).
} 
requires an appreciation and comprehension of the small-scale and everyday, a reclaiming of protest from below, to paraphrase EP Thompson. The eight-year period has of course been full of such minor acts of dissent ${ }^{11}$, which by their very nature registered with only a handful of observers. Those that had a wider reach would include a man who 'shoplifted' a kindle (and handed himself in to the police) in protest at the 'appalling behaviour' of its online customer service team ${ }^{12}$, tree protesters in Sheffield ${ }^{13}$, disability activists planning to block the concourse at London Bridge in rush hour in protest at reduced accessibility ${ }^{14}$, and, my favourite, 77 year-old John Fuller who organised a round-the-clock protest at the failure to bypass his Dorset village by repeatedly pressing the button on a pedestrian crossing, leaving the lights almost constantly on red! ${ }^{15}$

\section{HOW HAVE PROTESTERS AND ACTIVISTS FARED SINCE 2010?}

\footnotetext{
${ }^{11}$ I am drawing here on Mark Thomas's "100 Acts of Minor Dissent", from May 2013 to May 2014, culminating in a live five-hour stage show: http://www.markthomasinfo.co.uk/about/100-acts-of-minordissent/

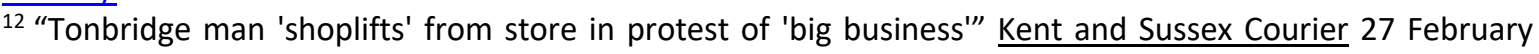
2015.

${ }^{13}$ Sheffield City Council v Fairhall and Others [2017] EWHC 2121 QB.

${ }^{14} \mathrm{D}$. Taylor 'Disability campaigners plan rush-hour protest at London Bridge station' The Guardian 5 April 2017 https://www.theguardian.com/society/2017/apr/05/disability-campaigners-plan-rush-hour-protestat-london-bridge-station access on 10 January 2018.

${ }^{15} \mathrm{~S}$ Morris "Anti-lorries protest brings traffic to halt at touch of a button" The Guardian 4 May 2010, https://www.theguardian.com/uk/2010/may/04/lorries-protest-pedestrian-crossing (access on 19 December 2017).
} 
In this main section, we assess how far the right of peaceful protest has been advanced and secured during the eight years since the Conservative/LibDem coalition took power. The picture painted is not an especially healthy one for more activist and transgressive protests, once we move away from the protection offered to the large-scale, formulaic protest: the placard-waving march or demonstration. The section is in four parts: developments at doctrinal level, whether that be legislative change or judicial decisions; operational policing practice; the involvement of and regulation by private law and private actors; and access to civic space, in both its literal and figurative sense. This article offers two different conceptualisations of protest: a narrower one, protest as (collective) event and, when we consider interruptive surveillance, political campaigning and access to space, a wider one, protest as process. ${ }^{16}$ That latter envisages the precursor organisational aspects - and thus provides us with a link between law and social movement theory.

\section{Doctrinal developments}

At the level of the formal legal rules, here there has been positive change. One of the Coalition's early moves, in October 2011, was a consultation on police powers to promote and maintain public order. One element was on the removal of the word "insulting" from s.5 of the Public Order Act 1986 (POA), leaving the crime as using threatening or abusive words or

\footnotetext{
${ }^{16}$ On which see generally V Aston "State surveillance of protest and the rights to privacy and freedom of assembly: a comparison of judicial and protester perspectives" (2017) 8(1) European Journal of Law and Technology 14.
} 
behaviour within the hearing or sight of a person likely to be caused harassment, alarm or distress. ${ }^{17}$ During the course of what became $\mathrm{s.57}$ of the Crime and Courts Act 2013, an amendment was moved in the House of Lords to achieve that result. This was initially resisted by the Government but in the Commons $2^{\text {nd }}$ Reading debate the Home Secretary said that whilst the Government supported the retention of s.5 as currently worded, it was "not minded" to challenge the amendment in the light of assurances from the DPP. ${ }^{18}$ The change came into effect on 1 February 2014.

This is clearly a liberalising measure. The textbooks and law courts are full of esoteric examples of insulting behaviour charges being used to limit political and dissentient speech, cases such as Hammond $v D P P^{19}$ and Norwood $v$ DPP. ${ }^{20}$ The Commons library noted the charges brought against a teenage anti-Scientology protestor and the well-publicised case of a student arrested for calling a police horse "gay", although in both cases, the charges were later dropped. In 2012, police in Lincolnshire threatened to arrest an atheist who displayed a poster in a window saying, all "religions are fairy stories". ${ }^{21}$ Going further back, s.5 was relied on to prosecute anti-abortion protesters who insulted a police officer with their

\footnotetext{
${ }^{17}$ On s.5 generally see A Geddis "Free speech martyrs or unreasonable threats to social peace - 'insulting' expression and section 5 of the Public Order Act 1986" [2004] PL 853. The LibDem pledge, recall, coming into the 2015 Election was to safeguard "offensive" non-violent protest, not something covered by s.5. 18 "'Insulting words or behaviour': Section 5 of the Public Order Act 1986" House of Commons Library Research Briefing 15 January 2013, available here http://researchbriefings.parliament.uk/ResearchBriefing/Summary/SN05760 (access on 19 December 2017).

${ }^{19}$ [2004] EWHC 69 Admin.

20 [2003] EWHC 1564 Admin.

21 "Christian Institute criticises police over atheist's poster" The Christian Institute 22 June 2012, http://www.christian.org.uk/news/christian-institute-criticises-police-over-atheists-poster/
} 
placards displaying aborted foetuses ${ }^{22}$, or those in Northern Ireland arrested for displaying a poster "Ireland: Twenty Years of Resistance" featuring four youths stoning an armoured car. $^{23}$

A fair conclusion could be that these types of cases should, if not disappear, at least reduce considerably in number and frequency. "Insult" was used as a catch-all, not something as easily open to police with the word "threaten". How far the word "abuse" might fill that discretionary policing gap is questionable. Data will reveal little, indicating simply that s.5 has been used, not which of the three, now two, verbs was in play. That said, the change might not have such a profound affect. The residual common law power to arrest or warn to desist on grounds that continued behaviour would constitute breach of the peace remains. While there is arrest data, it is impossible to know the scale of the problem when police 'merely' warn. We will never be able to tell if there had genuinely been a decrease in the police power to regulate dissent and protest, or simply a diversion. What those reports of the historic (and possibly continued) reliance on s.5 by the police tell us is the oftentimes chasm between law and practice. I have written elsewhere about possible ways that the seeming severity of $\mathrm{s.5}$ in the context of political expression might be tempered. ${ }^{24}$ The first is through reading the "reasonable conduct" defence in $\mathbf{s . 5}$ as always permitting the proportionate exercise of free speech rights under Article 10. The second, and not dissimilar route, was achieved

\footnotetext{
${ }^{22}$ DPP v Clarke (1991) 94 Cr App Rep 359 DC.

${ }^{23}$ Cited in C Gearty and K Ewing Freedom under Thatcher (OUP, 1990) 122.

${ }^{24}$ D Mead The New Law of Peaceful Protest: Rights and Regulation in the Human Rights Act Era (Hart, 2010) 223 et seq.
} 
in Percy $v$ DPP. ${ }^{25}$ There, the conviction by magistrates of a long-term peace campaigner, who placed the US stars and stripes flag on which she'd written "No To Star Wars", on the road outside a USAF airbase, was overturned by the Divisional Court. Technically, this was not a revisiting of s.5 considered "anew through the prism of section 3" of the HRA. ${ }^{26}$ Yet, it is sound evidence of the importance placed by (certain) courts on Article 10 in the context of protest. Such instances as the Lincolnshire poster or the reports that the Met were willing to utilise it against those protesting at the funeral of Margaret Thatcher in 2013 continue to show the difficulties of doctrinal development and case-law change percolating into operational policing.

The second legislative development which superficially sustains the claim that that 2010 pledge has been met, or at least that steps had been taken towards achieving it, was to the law that governed demonstrations in and around Westminster. The outright ban on unauthorised demonstrations had been the subject of contention since its introduction in 2005 in the Serious Organised Crime and Police Act of that year. It was repealed by $\mathrm{s} .141$ of the Police Reform and Social Responsibility Act (PRSA) 2011. However, this did not mean reversion to the status quo ante. Protests around Westminster were not going to be regulated on the same basis as elsewhere in England and Wales under the general provisions in ss.12-14A of the POA 1986. Instead, the PRSA 2011 introduced a power

\footnotetext{
25 [2001] EWHC 1125 Admin

${ }^{26}$ Mead n24, 225
} 
to control certain but varied activities in Parliament Square. ${ }^{27}$ First, this covers a much smaller area than under the 2005 scheme, which was about $1.25 \mathrm{~km}$ by $1.75 \mathrm{~km} .{ }^{28}$ Secondly, and to reiterate, the PRSA no longer effected an outright ban on unauthorised "demonstrations", howsoever they might be defined. Nonetheless, while the activities were not facially directed at or limited to protesting activities, s.143(2) of the PRSA defines what is proscribed: operating any amplified noise equipment; erecting or keeping erected in the controlled area any tent, or any other structure that is designed, or adapted, (solely or mainly) for the purpose of facilitating sleeping or staying in a place for any period; using any tent or other such structure in the controlled area for the purpose of sleeping or staying in that area; placing or keeping in place in the controlled area any sleeping equipment with a view to its use for the purpose of sleeping overnight in that area; and using any sleeping equipment in the controlled area for the purpose of sleeping overnight in that area.

While the latter are aimed at a certain type of obstructive or disruptive activism - occupation or camping out (such as the long-term peace camp of the original target of the 2005 restriction, Brian Haw) ${ }^{29}$ - it is hard to conceive how restricting use of loudspeakers or loudhailers would not bite on protests more generally anywhere. This must be especially so on Parliament Square given the traffic noise. The seemingly neutral scheme

\footnotetext{
${ }^{27}$ Policing practice indicates there might be issues over legal certainty - as to render any restrictions not prescribed by law. There were reports of them confiscating pizza boxes on the ground that these constituted, or were capable of constituting, "sleeping equipment": F Perraudin, "Occupy protesters forced to hand over pizza boxes and tarpaulin" The Guardian 24 October 2014 https://www.theguardian.com/world/2014/oct/24/occupy-protesters-forced-to-hand-over-pizza-boxesand-tarpaulin (access on 19 December 2017).

${ }^{28}$ Mead n24, 149 fn 156.

${ }^{29}$ As well as, as an aside, criminalising homelessness.
} 
still prioritises commercial activities, and discriminates those exercising their rights of free speech: we can probably presume that those using the chimes on ice cream vans around Westminster Square to attract custom, or those leading tour groups using microphones to amplify their voices are not directed to desist $(\mathrm{s} .143(1)){ }^{30}$ The new provisions have been the subject of unsuccessful challenge. In Gallastegui, the claimant argued, in part, that the ban on overnight sleeping created an effective ban on her ability to conduct a long-term protest given that she lived 70 or so miles away. ${ }^{31}$ The return daily travel costs were prohibitive. This, alongside all other aspects of her claim, fell on stony ground. The statutory scheme in s.143 et seq did not constitute a disproportionate interference with rights under Articles 10 and $11 .{ }^{32}$

Lastly, we should note one further significant statutory change that acts as a constraint on political protest. This is the introduction of Public Space Protection Orders (PSPOs) in s.59 of the Anti-social Behaviour, Crime and Policing Act $2014 .{ }^{33}$ This entitles local councils to make PSPOs to prevent or reduce unreasonable activities that are of a persistent or of a continuing nature, and which either have had or are likely to have a detrimental effect on the quality of life of those in the locality. The

\footnotetext{
${ }^{30}$ This is a point I have made frequently: we do not ban the queue outside Selfridge's for the first day of the sale, yet we ban protest marches or impose conditions on them: Mead n24, 417.

${ }^{31} R$ (oao Gallastegui) $v$ Westminster City Council and Others [2012] EWHC 1123 Admin though this was not a point pursued in the Court of Appeal [2013] EWCA Civ 28.

${ }^{32}$ See too the unsuccessful judicial review to challenge the decision of the Greater London Authority to erect and maintain fencing on and around Parliament Square Gardens, on grounds that it constituted a disproportionate interference with the rights in Articles 10 and 11: $R$ (oao Barda) $v$ Mayor of London [2015] EWHC 3584 Admin, the Occupy Democracy case.

${ }^{33}$ On which see generally K Brown "The hyper-regulation of public space: the use and abuse of Public Spaces Protection Orders in England and Wales" (2017) 37 LS 543, and more generally http://www.manifestoclub.com/ (access on 19 December 2017).
} 
potential for local councils to abuse and misuse this expansively, and uncertainly, defined power are obvious, for ordinary citizens and more sharply for those seeking to persuade others or simply to make public their opposition. Controversially, in October 2017, Ealing Council in London imposed a PSPO around an abortion clinic $^{34}$, and plans for a similar response in Portsmouth were floated. ${ }^{35}$ Using PSPOs to outlaw the use of amplified speakers - proposed for example by Birmingham in July 2015 obviously has repercussions for the exercise of the rights to free speech and to protest. ${ }^{36}$ More widely, the powers have been criticised as a crackdown on homelessness, begging and those on the margins. ${ }^{37}$

The fact that Parliament has produced what at best are marginal gains for those seeking socio-economic or political change through protests and other similar forms of mobilisation of course tells us only some of the story. The past eight years have been notable for significantly greater judicial engagement, and at a higher level than at any previous time, in the creation of "protest law". Until the early 2000s, protest cases that reached the appellate courts were scarce and far between, with Brutus v Cozens ${ }^{38}$ in 1973 on s.5 of the POA 1986 and DPP $v$ Jones and Lloyd in 1999 on

\footnotetext{
${ }^{34}$ BBC News "Ealing abortion clinic protest ban approved" 11 October 2017 http://www.bbc.co.uk/news/uk-england-london-41577129 (access on 19 December 2017).

${ }^{35}$ BBC News "Buffer zone plan for Portsmouth abortion clinic" 14 November 2017 http://www.bbc.co.uk/news/uk-england-hampshire-41990010 (access on 19 December 2017).

${ }^{36}$ Liberty press release "A shameful restriction on protest rights - Liberty urges Birmingham City Council to scrap PSPO plans" 21 July 2015 https://www.liberty-human-rights.org.uk/news/press-releases-andstatements/shameful-restriction-protest-rights-liberty-urges-birmingham-city (access on 19 December 2017).

${ }^{37}$ See B Garrett "PSPOs: the new control orders threatening our public spaces" The Guardian 8 September 2015 https://www.theguardian.com/cities/2015/sep/08/pspos-new-control-orders-public-spaces-asbosfreedoms (access on 19 December 2017).

38 [1973] AC 854.
} 
trespassory assembly two of few in recent memory. ${ }^{39}$ Indeed chapters on freedom of assembly or on protest in textbooks could be written authoritatively drawing on the same handful or so of cases, many of them dating back to the 1930s, and even to the late Victorian age.

The few years before the coalition came to power in 2010 brought us a steadier and more regular stream of House of Lords/Supreme Court cases: Laporte ${ }^{40}$ and Austin $^{41}$, both on breach of the peace, Kay v MPC on the power in s.11 POA 1986 to regulate processions, ${ }^{42}$ alongside $R v$ Jones ${ }^{43}$ and Gillan ${ }^{44}$, both involving protesters challenging more mainstream policing powers or substantive criminal law. The period since 2010 has seen no abatement. The following provides a flavour of the docket book, of both the UKSC and Court of Appeal. Perhaps unsurprisingly, none of the five below is a decision in favour of the protester. That is not to say that each, singly and collectively, is regressive. Findings in some provide positive glimmers of hope for protest law more widely. Together though, they though continue the historical norm favouring the state - or targets of protest - at the expense of those who resist or oppose.

In Richardson, the Supreme Court upheld a conviction for aggravated trespass (under s.68 of the Criminal Justice and Public Order Act (CJPOA) 1994) of an Occupied Palestinian Territory (OPT) activist who had locked-

\footnotetext{
${ }^{39}$ [1999] 2 AC 240.

${ }^{40} R$ (oao Laporte) v Chief Constable of Gloucestershire [2006] UKHL 55.

${ }^{41}$ Austin v Commissioner of Police for the Metropolis [2009] UKHL 5.

${ }^{42}$ Kay v Commissioner of Police for the Metropolis [2008] UKHL 69.

${ }^{43} R$ v Jones [2006] UKHL 16.

${ }^{44} R$ (oao Gillan) v Commissioner of Police for the Metropolis [2006] UKHL 6.
} 
on in a shop run by a subsidiary of an Israeli company operating out of the West Bank, within the OPT. In broad terms, aggravated trespass is made out where $X$, while trespassing on land, does anything there with the intention of obstructing or disrupting Y's lawful activities on that (or adjoining) land, or intimidating $Y$ so as to deter her. The shop sold beauty products labelled "Made by Dead Sea Laboratories Ltd, Dead Sea, Israel". In the Supreme Court's view, R was unable to avail himself of the argument that the activity he obstructed was not a lawful one, something that would have provided him with a defence to the charge. That was limited to acts or events that were "integral" to the occupant's activity on the land in question, not offences that were merely incidental or collateral such as (it was submitted here) cheating the Inland Revenue by falsely claiming the benefit of favourable terms reserved for goods properly deriving from Israel (as distinct from those produced in the OPT). That could not render their subsequent sale in the shop unlawful. At most, it meant that the shop was liable to repay the Revenue any duty which ought to have been paid but was not. The offence of aggravated trespass has been criticised rightly on various grounds - its uncertainty, its width, and the need for only a limited connection in time or place between the protest and the complained-about activity ${ }^{45}$, and thus the extra bite offered to the adjunct power in s.69 to give directions. Richardson simply expands the state's armoury by expanding the reach of the criminal law on peaceful, albeit disruptive, secondary direction action. While there might be echoes here of ban on secondary industrial action in s.224 of TULRCA 1992, there are very clear real differences. First, not only does Richardson

\footnotetext{
${ }^{45}$ See Winder v DPP (1996) 160 JP 713 DC, discussed Mead, n21, 260-261.
} 
not have the imprimatur of Parliament, there is no clear or necessary adjuration on the face of $\mathrm{s.68}$ for the interpretation adopted by the Court. It is very much a policy-oriented decision. Secondly, unlawful secondary industrial action does not expose trade unionists to prison. Thirdly, the nexus between protester, company and grievance seems closer in Richardson than in many secondary industrial disputes. The protesters' alleged claims that the shop had committed various crimes was never tested because they were not proximate enough. In essence, the protesters' claims were that the shop sales were a sine qua non of the continued production of beauty products and thus the continued existence of an economically viable but unlawful occupation by Israel.

Two protest cases from Northern Ireland have made their way to the Supreme Court. In JR38, a majority held that there was no violation of Article 8 where the police had released CCTV footage of a 14 year-old boy to local newspapers showing him committing public order offences during sectarian disorder. ${ }^{46}$ The police aimed to enlist public help in identifying him. The Court divided on whether or not Article 8 was even engaged, with only Lord Kerr and Lord Wilson holding that it was. In their view, the reasonable expectation test was contextual and account was needed of age, risk of stigma, consent and the use to which the material would be put. The Court was unanimous that, if Article 8 were engaged, publication was a proportionate response and thus a justified restriction on the right of privacy. In $D B \vee$ Chief Constable of PSNI, the Court concluded that in 2012 the police had misconstrued their legal powers to

\footnotetext{
${ }^{46}$ Re JR38's application for judicial review [2015] UKSC 42: Lord Clarke, Lord Toulson, Lord Hodge; Lord Kerr and Lord Wilson dissenting.
} 
stop parades passing through or adjacent to the nationalist Short Strand area of Belfast, the so-called flags protests. ${ }^{47}$ The police had determined they had no power to prevent parades that had not been notified to the Parades Commission, a requirement imposed on the proposed organiser by s.6(1) of the Public Processions (Northern Ireland) Act 1998. The Court determined that, since it was an offence under s.6(7) for both organisers and participants knowingly to organise or take part in an unnotified procession ${ }^{48}$, then the police had not simply the power, but by virtue of s.32 of the Police (Northern Ireland) Act 2000, the duty to prevent any unnotified march, such being in the Court's view, crimes. I have offered views on the case elsewhere. ${ }^{49}$ Simply put, the Court decision fails to accord any relevance to the fact that it is only a crime "knowingly" to take part in such a march. A blanket halting of a march is exactly that: no one can take part, whereas only those who should be arrested are those who knowingly take part in an unnotified march. Everyone is tainted with the guilt of everyone else, and an individualised right to protest is no longer that - protesters can be deprived of rights vicariously for the wrongdoing of another. It flies in the face of much Strasbourg jurisprudence including, interestingly, a case decided less than a week later, Lashmankin $v$ Russia. ${ }^{50}$ There the European Court of Human Rights, in finding against Russia, said this:

\footnotetext{
47 [2017] UKSC 7.

${ }^{48}$ The position in Northern Ireland is different to that in England and Wales where it is an offence only for organisers, under s.11(7) of the POA 1986.

${ }^{49}$ D Mead "Flagging up a misconception" Protest Matters blog 2 February 2017

https://protestmatters.wordpress.com/2017/02/02/flagging-up-a-misconception/ (access on 19 December 2017).

${ }^{50}$ App. no 57818/09, Judgment 7 February 2017.
} 
[The] enforcement of rules governing public assemblies, although important, cannot become an end in itself. In particular, where demonstrators do not engage in acts of violence it is important for the public authorities to show a certain degree of tolerance towards peaceful gatherings if the freedom of assembly guaranteed by Article 11 of the Convention is not to be deprived of all substance ... The Court considers that the authorities could have attained their goals by allowing the applicants to complete their protest and perhaps imposing a reasonable fine on the spot or later on. ${ }^{51}$ It is very hard to see $D B$ surviving Strasbourg scrutiny should the case be taken there.

The last two cases that make up the recent run in the Supreme Court are Catt and Hicks, which we shall come to momentarily when we consider policing practice. ${ }^{52}$ In both of those, again, the applicants were not successful. While all those Supreme Court were decided in favour of the police, we should not rush to conclude that is true of all court decisions in the past decade. Mengesha, discussed below, provides a curtailment of the common law power to take action to prevent breaches of the peace..$^{53}$ In the autumn of 2017, two peace campaigners were acquitted of criminal damage at a site owned by defence company BAE Systems after arguing they acted for the greater good. ${ }^{54}$ They said they were trying to stop

\footnotetext{
${ }^{51}$ At para 462

${ }^{52} R$ (oao Catt) $v$ Commissioner of Police for the Metropolis [2015] UKSC 9.

${ }^{53} R$ (oao Hicks) $v$ Commissioner of Police for the Metropolis [2017] UKSC 9.

${ }^{54}$ BBC News "'Greater good' pair cleared of BAE criminal damage" 26 October 2017

http://www.bbc.com/news/uk-england-lancashire-41763568 (access on 19 December 2017).
} 
Tornado jets being used by Saudi Arabia to bomb Yemen. A district judge in Burnley accepted their beliefs were sincerely held and found them not guilty. In December 2017, magistrates found an anti-fracking campaigner not guilty of obstructing the police at a shale gas site near Blackpool. ${ }^{55}$ Lastly, and in passing, we should note the potential for one measure propounded by the CPS to re-orientate the criminal justice system, at a formal level at least, in favour of protesters. In March 2012, the DPP introduced new guidance for prosecutors in public protest cases which included for the first time exacerbating and mitigating public interest factors that would militate against prosecution. ${ }^{56}$ The latter were: was the public protest essentially peaceful?; did the suspect have no more than a minor role?; did the suspect have no previous relevant history of offending at public protests or in general?; was the act committed minor?; and was the act committed instinctive and in the heat of the moment?

\section{Policing Practice}

The major epistemological breakthrough in legal scholarship over the last thirty or so years has been the recognition of the limits of the law, as either a regulator of social relationships or as predictor of behaviour. In this, scholars of protest law have benefitted enormously from insights gleaned from policing scholars.

\footnotetext{
${ }^{55}$ Drill or Drop News "Businessman considers legal action against police after acquittal for obstruction at anti-fracking protest" 19 December 2017, https://drillordrop.com/2017/12/19/businessman-considerslegal-action-against-police-after-acquittal-for-obstruction-at-anti-fracking-protest// (access 19 December 2017).

${ }^{56}$ CPS Legal Guidance: Public Protests available here http://www.cps.gov.uk/legal/p to r/public protests/ (access on 19 December 2017).
} 
Drawing on examples from, and in the context of, the USA, Alex Vitale offers us a fifty-year typography of four models of protest policing: escalated force, negotiated management, the Miami model, and command and control. ${ }^{57}$ There are certainly elements of many of these four in policing practice in the UK since 2010 , but as instructive is a fifth, offered Patrick Gillham, Bob Edwards and John Noakes, what they term "strategic incapacitation". 58 The predicate of this is preventing citizens from committing crime and causing disruption or disorder, with an emphasis on the control of space, and on surveillance and information sharing. It has two limbs, what we might term pre-crime policing and panoptical policing.

The preventive turn in criminal justice policy is now widely accepted, albeit that it remains contested. ${ }^{59}$ Its application to policing is no different. Pre-emptive, pre-crime policing is typified by indiscriminate and largescale arrests, using wide discretionary powers, followed by release without charge. It is designed either to intimidate and to chill, or simply incapacitate - or both. The police have been aided in this by the way in which protest has been securitised - the framing of social or political problems through a (national) security or counter-terrorism lens, thus to legitimise even more controls and constraints or to enhance the priority its control and constraint is given. Most notable here has been the use of

\footnotetext{
${ }^{57}$ A Vitale "From Negotiated Management to Command and Control: How the New York Police Department Polices Protests" (2005) 15(3) Policing and Society, 283. The fours are typified by, in turn,: force meeting force, in the 1960s; cooperation, communication, tolerating disruption and limited force; aggressive dispersal; and inflexible, zero tolerance policing based on "hierarchical micro-management of protests".

${ }^{58} \mathrm{P}$ Gillham, B Edwards and J Noakes "Strategic incapacitation and the policing of Occupy Wall Street protests in New York City, 2011" (2013) 23 Policing and Society 81.

${ }^{59} \mathrm{H}$ Carvalho, The Preventive Turn in Criminal Law (Oxford University Press, 2017), P Lawrence "The Vagrancy Act 1824 and the Persistence of Pre-emptive Policing in England since 1750" (2017) 57 Brit J Crim 513.
} 
counter-terrorism arrest, detention and questioning powers - as occurred in Gillan, for example ${ }^{60}$ or to which the sister of the journalist Owen Jones was subjected ${ }^{61}$ - or the labelling by police of political activists as "nonviolent extremist" or "domestic extremist" and thus subjecting them to surveillance and other measures under the Government's antiradicalisation agenda. ${ }^{62}$

The eight-year period is full of examples of that preventive turn. In November 2011, officers from the Metropolitan Police arrested over 150 EDL supporters to prevent a breach of the peace. The indications were that the group had planned to attack the Occupy LSX camp near St Paul's cathedral. ${ }^{63}$ In December 2014, 76 were arrested at a die-in being staged in the Westfield shopping centre to signify support for Eric Garner, a black man who died during an arrest in the US earlier that summer. ${ }^{64}$ While not technically pre-crime policing, the arrests of 145 UK Uncut activists following a temporary sit-in and protest in Fortnum and Masons in March 2011, on the day of the TUC day of action, also illuminate. A few were released without charge the following, leaving 138 charged with

\footnotetext{
${ }^{60}$ Gillan n?

${ }^{61} \mathrm{O}$ Jones "If my sister can be drawn into the anti-terror net, imagine the risk to others" The Guardian 26 October 2017 https://www.theguardian.com/commentisfree/2017/oct/26/schedule-7-terrorism-act-2000activism-civil-rights-ethnic-minorities (access on 19 December 2017).

${ }^{62}$ See as just one example of many on the Netpol News webpage "Counter-terror police contact parents of Birmingham student protester over alleged 'domestic extremism" 15 July 2014

https://netpol.org/2014/07/15/prevent-birmingham-student-protest/ (access on 19 December 2017). See more widely https://netpol.org/campaigns/together-against-prevent/

${ }^{63}$ S Laville "Police arrest EDL supporters 'to prevent breach of peace'" The Guardian 11 November 2011 https://www.theguardian.com/uk/2011/nov/11/police-arrest-edl-supporters-peace (access on 19 December 2017).

${ }^{64}$ BBC News "Eric Garner death: 76 arrested at London Westfield demo" 11 December 2014 http://www.bbc.co.uk/news/uk-england-london-30424338 (access on 19 December 2017).
} 
trespassory assembly. By July, charges against all bar about 30 had been dropped. ${ }^{65}$

One pre-crime policing incident that made its way up and through the courts is Hicks, arising from the Royal Wedding protests in April 2011. The Met arrested about 75 people in and around London either on the day or the night before the wedding on the basis that the police reasonably believed it was necessary to prevent an imminent breach of the peace. ${ }^{66}$ Some were participating in the Right Royal Orgy in Soho Square, some arrested after they were found to have climbing equipment and antimonarchy placards, and 21 were arrested during raids of five squats in London the previous day. One of them was planning to behead an effigy of Prince Andrew with a theatrical guillotine in a piece of street theatre, while four were dressed as zombies (with one wearing a "marry me instead" Tshirt). All were released without charge once the wedding was over and the police considered the risk of a breach of the peace had been passed. Their period of custody ranged from two-and-a-half to five-and-a-half hours. Four brought test cases, on behalf of 15 others, alleging that the arrests were unlawful, constituting a violation of Art 5 of the ECHR. The applicants lost in all three courts - the Administrative Court, the Court of Appeal, and the Supreme Court - though not on the same basis. The Supreme Court held that Art 5(1)(b) did not cover arrests such as these, a general obligation not to commit a breach of the peace not being "an obligation prescribed by law", but did hold that arrest and detention for

\footnotetext{
${ }^{65}$ S Malik "Fortnum \& Mason protest: CPS drops charges against 109 UK Uncut activists" The Guardian 18 July 2011 https://www.theguardian.com/uk/2011/jul/18/fortnum-mason-uk-uncut-charges-dropped (access on 19 December 2017).

${ }^{66} \mathrm{R}$ Booth, S Laville and S Malik "Royal wedding: police criticised for pre-emptive strikes against protesters" The Guardian 29 April 2011 https://www.theguardian.com/uk/2011/apr/29/royal-wedding-police-criticisedprotesters (access on 19 December 2017).
} 
preventive purposes followed by early release came within Art 5(1)(c). ${ }^{67}$ In doing so, the Court specifically adopted the minority view of the Strasbourg Chamber in the Ostendorf case. ${ }^{68}$ There are concerns here. First, those involved in Hicks had no previous convictions (or none for 20 years), no record of trouble, and no (recent) adverse interactions with police. Secondly, Ostendorf involved football fans not protesters so that, as a consequence, the exercise of other protected Convention rights was not in issue. Hicks is thus a very acontextualised decision, something that is all the more striking if compared with another of the Supreme Court's recent Art 5 cases a month before, Serdar Mohammed, arising from the military operations in Afghanistan and Iraq, a very expansive and contextualised decision. ${ }^{69}$

Combining mass arrests with the imposition of police bail makes a heady and invasive brew. That has been a matter of considerable contention among activists. The police have the power to impose pre-charge bail where there is insufficient evidence to charge, with suspects released pending further investigation. Where bail is imposed under s.37(2) of PACE 1984 (rather than under s.34), conditions can be imposed. Only from April 2017, has there been a time limit - 28 days - for police bail. ${ }^{70}$ Previously it could be in place indefinitely. In 2012, 182 cyclists arrested on the London Critical Mass on the night before the Olympics opening ceremony were subject to bail conditions including a requirement not to cycle anywhere in the borough of Newham, and not to go within $100 \mathrm{~m}$ of any

\footnotetext{
67 Hicks $\mathrm{n}$ ?.

68 Ostendorf v Germany [2013] ECHR 197.

${ }^{69}$ Mohammed v Ministry of Defence [2017] UKSC 2.

${ }^{70}$ Section 62 of the Police and Crime Act 2017.
} 
Olympic venue, placing significant restrictions on work, movement and family life. ${ }^{71}$ Figures obtained by The Guardian in 2014 indicated that at least 732 people had been banned by police forces in England and Wales since 2008 , but then never charged, $85 \%$ of those barred from protesting when bailed. ${ }^{72} \mathrm{Netpol}$, the network for policing monitoring, reports how many of those bailed have had specific conditions banning them from associating with other named persons, or with more than four others, and even bans on participating in future protests. Some conditions have been as wide, and as vague, as bans on entering "central London". ${ }^{73}$

Another tool in the armoury since 2014 has been the power to order protesters, and others, to disperse contained in s.35 of the Anti-social Behaviour, Crime and Policing Act 2014. ${ }^{74}$ This too has been subject to considerable criticism, that it has been both misused and overused. ${ }^{75} \mathrm{~A}$ constable in uniform may direct any person in a public place in the locality

\footnotetext{
${ }^{71}$ S Malik "Critical Mass arrests: police charge three" The Guardian 29 July 2012 https://www.theguardian.com/uk/2012/jul/29/critical-mass-police-arrest-three (access on 19 December 2017).

$72 \mathrm{~K}$ Rawlinson "Revealed: Police using pre-charge bail to muzzle protesters" The Guardian 25 December 2014 https://www.theguardian.com/uk-news/2014/dec/25/revlealed-police-using-pre-charge-bail-muzzleprotesters (access on 19 December 2017).

${ }^{73} \mathrm{Netpol}$ "Netpol calls for abolition of police bail conditions for protest arrests" 22 July 2014 https://netpol.org/2014/07/22/abolish-police-bail/\#more-2339 (access on 19 December 2017).

${ }^{74} \mathrm{It}$ requires an inspector (or higher rank) previously to have authorised the use of the $\mathrm{s} .35$ power in a specified locality, under s.34. They might do so only if satisfied on reasonable grounds that the use of that power might be necessary for the purpose of removing or reducing the likelihood of (a) members of the public in the locality being harassed, alarmed or distressed, or (b) the occurrence in the locality of crime or disorder. In deciding whether to give such an authorisation an officer must have particular regard to Arts 10 and 11.

${ }^{75}$ Football fans have also complained about their subjection to police dispersal powers. These powers operate alongside and in addition to that were ASBOs (anti-social behaviour orders) and since 2014 CBOs (criminal behaviour orders), themselves with a long pedigree of constraining protesters: see Mead n24, 362364, and more recently ASBOS imposed on anti-Olympics protesters in 2012: P Walker "Protester receives Olympics asbo" The Guardian 17 April 2012 https://www.theguardian.com/society/2012/apr/17/protesterreceives-olympic-asbo (access on 19 December 2017) and on members of the EDL in 2010 restricting their access to Birmingham until 2020: BBC News "Travel ban for English Defence League Birmingham men" 17 December 2010 http://www.bbc.co.uk/news/uk-england-12024824 (access on 19 December 2017).
} 
specified in the authorisation to leave and not to return (for up to 48 hours) if they have reasonable grounds to suspect that the person's behaviour has contributed or is likely to contribute to either (a) members of the public in the locality being harassed, alarmed or distressed, or (b) the occurrence in the locality of crime or disorder. The officer must also consider that giving a direction is necessary for the purpose of removing or reducing the likelihood of harassment, alarm or distress, or of crime or disorder. Netpol reported how Merseyside Police imposed a dispersal order against anti-fur activists in Liverpool city centre - despite the fact that they were not even protesting at the time - and against a peaceful anti-fascist counter-demonstration opposing a National Front 'day of action', even though the far right group failed to show up. ${ }^{76}$ Again, there is evidence of considerable overreach, and - as with many aspects of protest policing - formulaic recantation of limited reasons. A group who had been evicted from an anti-fracking site in Cheshire were ordered to disperse from an area covering not simply the former site but a five square mile area around it. The written notice indicated as the reason for the order was "protest site", indicating the false conflation of protest with harassment, alarm or distress. ${ }^{77}$ There have been challenges - based on the paucity of reasoning ${ }^{78}$ or because it seems the police have simply imposed them en masse without consideration of individual culpability. ${ }^{79}$ These latter resemble the challenges to football banning orders (FBOs) in

\footnotetext{
${ }^{76} \mathrm{Netpol}$ "New dispersal order powers used against Southwark housing campaigners" 19 February 2015 https://netpol.org/2015/02/19/dispersal-orders-aylesbury-estate/ (access on 19 December 2017).

${ }^{77} \mathrm{Netpol}$ "Cheshire Police issue restrictive dispersal orders to Upton anti-fracking protesters" 15 January 2016 https://netpol.org/2016/01/15/section-35-upton-fracking-camp/ (access on 19 December 2017). ${ }^{78} \mathrm{Ibid}$

${ }^{79}$ Football Supporters' Federation "Wrexham fans challenge new police powers... and win" 18 January 2017 http://www.fsf.org.uk/blog/view/wrexham-fans-challenge-new-police-power-and-win-legal-precedent (access on 19 December 2017).
} 
the case of Gough, where the Court of Appeal made it clear that proportionate police decision-making action required that restrictions be imposed only after giving individual consideration to each affected person. $^{80}$

We see this too in the continued reliance on containment, or kettling, another feature of the policing of protest that has continued over the past decade. Largely, this has been because of the judicial approval offered to the practice by both the courts in the UK, and at Strasbourg, in Austin. There, in 2012, the Grand Chamber broadly followed the House of Lords, holding that kettling did not generally engage the right not to be deprived of liberty in Article 5. The Court did not rule that it never could but provided no indicia of how we might tell, so that on the facts, being confined in small area on Oxford Street, for several hours, during the May Day protests in 2001 did not constitute a deprivation of liberty. That being so, there was no need for the police to justify the containment, under Arts $5(1)(a)-(f)$, something that would have proved very difficult. The case has been subject to considerable criticism - largely for the acontextual nature of the decision, its deviation from previous Art 5 case law, and for the flaws in its reasoning by analogy ${ }^{81}$ - but it marks the boundary of legally acceptable coercive mass policing. Austin "edges us towards [what in the UK is the] hitherto unknown concept of an illegal gathering, dealing with

\footnotetext{
${ }^{80}$ [2002] EWCA Civ 351 [68].

${ }^{81}$ For a critique, M Hamilton "Guest Post on Austin and Others Grand Chamber Judgment on 'Kettling'" 23 March 2012 http://echrblog.blogspot.co.uk/2012/03/guest-post-on-austin-and-others-grand.html and D Mead "When kettling comes to the boil before the Strasbourg Court: is it a deprivation of liberty to contain protesters en masse?" (2012) 71 CL 472.
} 
protesters en masse based on suspicions of a few". ${ }^{82}$ That approach, misconceived as I consider it to be, garners support more recently in $D B$, as we saw above..$^{83}$

Rays of light have been rare. In 2013, the High Court held that the policing practice of demanding personal details, and filming protesters, as a condition of release from containment was not lawful. This is welcome. Moses LJ explained why.

Containment is not permissible for some purpose other than to prevent a breach of the peace which is taking place or reasonably thought to be imminent. In particular, it is not permitted as a means of ensuring that the identification of those contained has been obtained by questioning and by filming. It is the limited and confined purpose for which containment may be imposed which reveals that containment for the purpose of obtaining identification is unlawful. ${ }^{84}$

Against that is weighed a case such as Wright, the first challenge before the domestic courts to the practice, imported from the US, of physically penning in protesters. ${ }^{85}$ Wright claimed damages for false imprisonment and assault for the 15-minute period he spent in a small area defined by

\footnotetext{
${ }^{82}$ D Mead "The Right To Protest Contained By Strasbourg: An Analysis of Austin v. UK \& The Constitutional Pluralist Issues it Throws Up" UK Constitutional Law Association blog, 16 March 2012 https://ukconstitutionallaw.org/2012/03/16/david-mead-the-right-to-protest-contained-by-strasbourg-ananalysis-of-austin-v-uk-the-constitutional-pluralist-issues-it-throws-up/ (access on 19 December 2017).

${ }^{83} \mathrm{X}$-ref at proof stage

${ }^{84}$ Mengesha $v$ Commissioner of Police for the Metropolis [2013] EWHC 1695 (Admin) [12].

${ }^{85}$ Wright v Commissioner of Police for the Metropolis [2013] EWHC 2739 (QB), discussed D Mead "The (police) pen is mightier than the sword" ProtestMatters blog 11 September 2013 https://protestmatters.wordpress.com/2013/09/11/the-police-pen-is-mightier-than-the-sword/ (access on 19 December 2017). We could add here for completeness $R$ (oao Moos and McClure) $v$ Commissioner of Police for the Metropolis [2012] EWCA Civ 12 and Castle v Commissioner of Police for the Metropolis [2011] EWHC 2317 Admin, in both of which the applicants failed.
} 
barriers and railings, having shouted "Shimon Peres is coming this way", during his state visit to London. The High Court held that the police had made out their case, premised on preventing what they reasonable perceived was an imminent breach of the peace. Wright swings the pendulum considerably back in favour of the police. His Lordship had two concerns. Wright's words would provoke others in his group to attack or approach Peres' car, ${ }^{86}$ and a worry that the Israeli security team might "have responded with a greater degree of robustness than British police officers ...to a hand in the pocket". ${ }^{87}$ In short, Wright was penned in not as a result of anything he said or did, but out of a fear for the reaction of others, whether they be other protesters or agents of a third-party state. Neither is sufficient. None of the usual cases referred to in the judgment, dating back to the usual Victorian cases - Beatty $v$ Gillbanks ${ }^{88}$ and Wise $v$ Dunning $^{89}$ - is really precedent for that first worry. Even if they were, they could surely be distinguished on the basis of lack of any inflammatory language - hence the relevance of Redmond-Bate, where the citizen was successful. ${ }^{90}$ Further, Jay $\mathrm{J}$ - despite asserting that he should avoid doing so - seems to have conflated two separate legal questions: the reasonableness of the police apprehension and the reasonableness of the protester's actions, or words. ${ }^{91}$

An equally, and likelier more, worrying trend both in the UK and globally over the past decade or so has been the increased use of surveillance

\footnotetext{
${ }^{86}$ Wright ibid [61].

${ }^{87}$ Ibid [45].

${ }^{88}$ (1882) 9 QBD 308.

${ }^{89}$ (1902) 1 KB 162.

${ }^{90}$ [2000] HRLR 249.

${ }^{91}$ Ibid [66].
} 
technology, and reliance on its product. ${ }^{92}$ There are various elements to this and subjecting activists to surveillance serves a variety of purposes. Most notably, this is where the change has been. Surveillance - whether by CCTV or ANPR, or open source monitoring of social media traffic, or more physical forms such as by FIT or undercover officers - is now no longer designed to obtain evidence for charge, or indeed prevention of identifiable activities. It is used now as much to chill protesters more generally, to deter, and to disrupt both activities and organisational capacity.

In 2015, the Supreme Court (by a majority, Lord Toulson dissenting) sanctioned the gathering and retention of personal data as not violating the right of privacy contained in Art $8 .^{93}$ John Catt, an 85 year-old peace campaigner, challenged the practice of taking photographs and recording other details of his attendance at political events and participation in activism directed against arms manufacturer EDO in Brighton. Some members of "Smash EDO" had previously committed violent offences. The police overtly collected information from Smash EDO public demonstrations. Because Smash EDO had associations with violent crime, information was retained even where no crime had been committed. Catt made a subject access request under the Data Protection Act 1998 and discovered that what was then the NPOIU (National Public Order

\footnotetext{
${ }^{92}$ This is not the place to discuss surveillance as process, on which see e.g. P Gill and M Phythian, Intelligence in an insecure world (Polity 2006). Surveillance here is being used as shorthand for a range of monitoring techniques.

${ }^{93}$ Catt n?.
} 
Intelligence Unit ${ }^{94}$ ) held details of his appearance, his vehicle, demonstrations he had attended and other personal details, in 107 separate records. The majority (Lord Sumption giving the leading judgment) held that taking such information and making such records did not constitute a disproportionate interference. His Lordship provided various reasons why the interference with private life was minor: the information was personal but not intimate or sensitive; the primary facts recorded had always been in the public domain, and it was known that the police recorded them; there was no stigma attached to the inclusion of his information in the database as part of reports primarily directed to the activities of other people; the material was usable and disclosable only for police purposes and in response to requests made by Mr Catt himself under the Data Protection Act; and the material was regularly reviewed for deletion according to rational and proportionate criteria contained in the publicly available Code of Conduct and Guidance. Furthermore, His Lordship continued, there were numerous proper policing purposes to which the retention of evidence of this kind made a significant contribution. The longer-term consequences of restricting the availability of this method of intelligence-gathering to the police would potentially be very serious, and the amount of labour required to excise information relating to persons such as $\mathrm{Mr}$ Catt from the database would be disproportionate. Lord Toulson could see no necessity justifying retention for many years after the event information about someone about whom the police had concluded that he was not known to have acted violently. It was hard to see how information retained concerning attendance at

\footnotetext{
${ }^{94}$ This became the Domestic Extremism Unit, and most recently the National Counter Terrorism Police Operations Centre.
} 
mainstream political protest events could ever be thought necessary and proportionate. The suggestion that it would be over-burdensome for the police to have to review information about individuals such as Mr Catt was not supported by the evidence, especially since the police already conducted regular reviews.

The Supreme Court in Catt, and courts in other cases - such as Wood ${ }^{95}$ - have taken a narrow view of what constitutes privacy and private life, generally subscribing to the view that what happens, and is observable, in public places cannot also be private information. ${ }^{96}$ This is a peculiarly locational conceptualisation of privacy, though by no means an uncommon one. For the Supreme Court in Catt it was what happened to that information once it was obtained that transformed it into an aspect of private life: "it is clear that the state's systematic collection and storage in retrievable form even of public information about an individual is an interference with private life." 97 This is problematic conceptually - if privacy is concerned with autonomy and dignity, as the House of Lords held in Campbell, then where that control is exercised is secondary, if not redundant ${ }^{98}$ - and practically. It means for example that police are able without even engaging a citizen's rights to a private life (let alone justify any interference as proportionate) to conduct open source surveillance of social media sites, such as Facebook and Twitter. Brighton queer activist Beth Granter had a visit from Sussex police wishing to ask her some questions about a planned Pride beach $B B Q$ - about which she knew

\footnotetext{
${ }^{95}$ Wood $v$ Commissioner of Police for the Metropolis [2009] EWCA Civ 414.

${ }^{96}$ See generally Aston above $n$ ? and also https://privacyinternational.org/node/1481

${ }^{97}$ Catt n?? [6] Lord Sumption.

${ }^{98}$ Campbell v MGN [2004] UKHL 22.
} 
nothing until they arrived. Their information was based, it seems, on monitoring a general LGBQT Facebook page with which she had had some previous involvement. ${ }^{99}$ Not only does this engage, and have a significant and detrimental impact an on individual's privacy, Val Aston also suggests - and backs this up with convincing empirical data from activists - that surveillance has

a decisive impact on the capacity and capability of protest groups to achieve successful mobilisations... [undermining] some of [their] key building blocks...: i) the perceived legitimacy of protest groups; ii) the mobilisation potential of protest groups; and iii) their access to resources. ${ }^{100}$

The other major concern to have played out throughout the period has been the use of undercover officers embedded within activists' groups and networks, many of them having developed relationships with women (in almost all cases) and had children with them. ${ }^{101}$ The issue first came to light in 2010 when the trial of environmental campaigners, accused of conspiracy to commit aggravated trespass at Ratcliffe-on-Soar Power Station, collapsed. The CPS withdrew the case once it became known that PC Mark Kennedy (known as Mark Stone) had not only infiltrated the group over a eight year period, but had acted as agent provocateur on several occasions. The CPS had not originally disclosed Kennedy's involvement in the Ratcliffe action, nor that his identity, and testimony, was

\footnotetext{
${ }^{99}$ Beth Granter's blog "Police intimidation of queer anti-austerity activist in Brighton" 1 August 2014 http://bethgranter.com/blog/2014/08/police-intimidation-of-queer-anti-austerity-activist-in-brighton/ (access on 19 December 2017).

100 Aston n? 9

${ }^{101}$ See generally R Evans and P Lewis Undercover: the true story of Britain's police force (Faber and Faber, 2013).
} 
false. Many took the identities of deceased children. So far, it is known that at least 144 officers subjected over 1000 groups to monitoring and surveillance. ${ }^{102}$ In 2015, the Home Secretary announced she was establishing an independent inquiry, under Sir Adrian Fulford, and now under Sir John Mitting. ${ }^{103}$ Its purpose is to

investigate and report on undercover police operations conducted by English and Welsh police forces in England and Wales since 1968. The Inquiry will examine the contribution undercover policing has made to tackling crime, how it was and is supervised and regulated, and its effect on individuals involved - both police officers and others who came into contact with them. ${ }^{104}$

Throughout 2016 and 2017, the Inquiry has been determining preliminary issues such as applications for anonymity, and determining the core participants. Undercover policing has also triggered its own litigation, in both common law and under the HRA, from the women tricked into forming relationships. ${ }^{105}$ In turn, this has led to satellite litigation, such as the challenges by the women to the Met's NCND policy, Neither Claim Nor Deny, in relation to the officers, with the Met successfully arguing that the

\footnotetext{
102 R Evans "Undercover police spied on more than 1,000 political groups in UK" The Guardian 27 July 2017 https://www.theguardian.com/uk-news/2017/jul/27/undercover-police-spied-on-more-than-1000political-groups-in-uk access on 19 December 2017).

${ }^{103}$ The Inquiry's website is here https://www.ucpi.org.uk/

${ }^{104}$ The Inquiry is very clearly limited to England and Wales, despite evidence of cross-border cooperation with both Scottish and Northern Irish officers, as well as pan-European: T Gordon "Theresa May blocked Scottish inquiry into spies having sex with female activists" The Herald 12 September 2017 http://www.heraldscotland.com/news/15529897.Inquiry into spies having sex with female activists wa s blocked in Scotland/ (access on 19 December 2019). Permission has been given to bring judicial review proceedings to challenge the refusal to extend the Inquiry to cover Scotland: C Marshall "Theresa May blocked Scottish inquiry into spies having sex with female activists" The Herald 14 September 2017 http://www.scotsman.com/news/politics/legal-win-for-undercover-policing-campaigners-1-4560043 (access on 19 December 2019).

${ }^{105}$ For more, see https://policespiesoutoflives.org.uk/law/
} 
HRA cases should be heard in secret before the Investigatory Powers Tribunal. Most recently, in August 2017, the Met wrote to one of the women, Helen Steel, demanding payment of $£ 7000$ costs after she withdrew the appeal in relation to one of those NCND challenges. Steel had been trying to force the Met to disclose that her former boyfriend, John Dines, had been an undercover officer. ${ }^{106}$ It also came to light that what is now the National Counter Terrorism Police Operations Centre had placed leading Green Party politicians under surveillance. Files show that the police had chronicled how the Green politicians, such as the party's sole MP Caroline Lucas, the party's candidate for Mayor of London, Sian Berry and one of the party's London Assembly members, Jenny Jones, had been speaking out about issues such as government cuts, the far right, police violence, and the visit of the pope. None of these matched the more limited scope given to the unit's activities by the then Met Police Commissioner, Sir Bernard Hogan-Howe, in October 2013. Its focus would be on individuals who committed or planned "serious criminal activity motivated by a political or ideological viewpoint" and would usually exclude "low levels of civil disobedience such as civil trespass or minor obstruction" ${ }^{107}$

It is impossible to square this oftentimes routine surveillance of activists and politicians with what was a notable shift in the official policing position at the start of the decade. Senior officers, HMIC reports, and

\footnotetext{
${ }^{106} \mathrm{R}$ Evans "Woman deceived by police spy refuses to pay Met legal bill" The Guardian 28 August 2017 https://www.theguardian.com/uk-news/2017/aug/28/woman-deceived-by-police-spy-refuses-to-pay-metlegal-bill (access on 19 December 2019).

${ }^{107} \mathrm{R}$ Evans and V Dodd "Police anti-extremism unit monitoring senior Green party figures" The Guardian 28 April 2016 https://www.theguardian.com/politics/2016/apr/28/police-anti-extremism-unit-monitoringgreen-party-caroline-lucas-sian-berry (access on 19 December 2017).
} 
training manuals all came to recognise the duty to facilitate protest as a guiding principle in both planning and on-the-day operational decision making. In 2009, the first immediate recommendation in the HMIC report "Adapting to Protest" was that in planning future public order operations for protest, the police should "demonstrate explicit consideration of the facilitation of peaceful protest", ${ }^{108}$ something recognised and developed in its follow-up report a year later "Adapting to Protest: Nurturing the British Model of Policing". We see it too in the 2010 reworking of the ACPO Guidance "Keeping the Peace" which talks of the starting point for policing peaceful protest being the presumption in favour of facilitating peaceful assembly. ${ }^{109}$ It is certainly something that has made its way into the everyday discourse of senior officers, such as Gold and Silver Command. Merseyside police indicated in September 2015, in the context of plans by neo-Nazis to march, that there were "no grounds to make an application to ban the march. In accordance with the Human Rights Act 1998, the force will facilitate peaceful protest." 110 Staffordshire police in August 2014, of direct action sit in against an arms manufacturer, similarly asserted they "had to carefully balance our role in facilitating peaceful protest against any unlawful impact on the wider community."111

\footnotetext{
${ }^{108}$ Her Majesty's Inspectorate of Constabulary report "Adapting to Protest", July 2009, 10, available here https://www.app.college.police.uk/app-content/public-order/linked-reference-material/. 109 "Keeping the Peace" p.25

$110 \mathrm{~J}$ Thomas "Neo Nazi fascists set to march through Liverpool tomorrow - three weeks after being forced to call off racist rally? Liverpool Echo 4 September 2015

http://www.liverpoolecho.co.uk/news/liverpool-news/neo-nazi-fascists-set-march-9991816 (access on 19 December 2017).

${ }^{111}$ P Suart and A Richardson "All nine Shenstone factory protesters charged with aggravated trespass" Birmingham Mail 8 August 2014 http://www.birminghammail.co.uk/news/midlands-news/nine-shenstone-factory-protesters-charged7581314 (access on 19 December 2017).
} 
Whether this filters downwards to officers on the street is moot. In the policing context more widely, research has shown that the HRA has had limited effect on everyday, street level policing decisions. Instead, it simply provides a frame for ex post facto explanations and rationales - for giving an account, not for accountability. ${ }^{112}$ There is also the feeling of the police themselves being unsure the extent of their duty. It remains common to read or hear of the police talking about the duty to facilitate lawful protest, a very different - and much narrower concept - than peaceful protest. In the lead-in to the Labour Conference in Brighton in 2017, Sussex police tweeted ${ }^{113}$

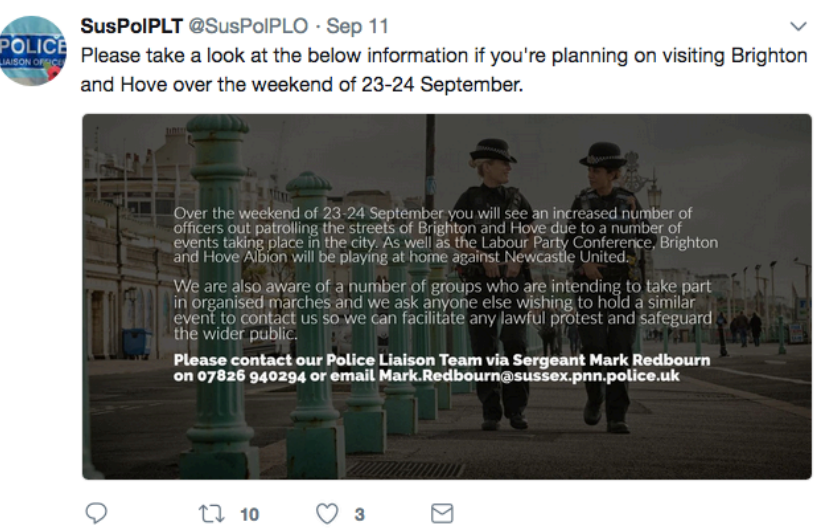

As another example, in July 2015 Chief Inspector Gareth Parkin, after disturbances during anti-austerity protests, stressed that Greater Manchester Police was "committed to facilitating lawful protest". 114

\footnotetext{
${ }^{112}$ See K Bullock and P Johnson "The impact of the Human Rights Act 1998 on policing in England and Wales" (2011) 52 Brit J Crim 630. This is consistent with the author's own informal observations from the control room of policing a protest with a clear divergence between senior commanders and officers on the street as to what constituted a "good day".

113 Tweet from @SusPoIPLO 09:00, 11 September 2017 https://twitter.com/SusPolPLO (access on 19 December 2017).

${ }^{114} \mathrm{P}$ Bainbridge "Seven arrested in Piccadilly Gardens after homeless man attacked and Tesco Express damaged" Manchester Evening News 17 July 2015 http://www.manchestereveningnews.co.uk/news/greater-manchester-news/seven-arrested-piccadillygardens-after-9675506 (access on 19 December 2017).
} 
Another of Vitale's four typologies of policing styles was negotiated management. ${ }^{115}$ We can see evidence that the new duty to facilitate, reflecting the Strasbourg Court's positive obligations jurisprudence in such cases as Plattform Ärtzte $v$ Austria $^{116}$, has gained traction in the UK over the past decade through the expansion in protest liaison officers/teams (PLOs). They can be seen in their distinctive blue tabards at most major events. The use made of what has been termed "strategic facilitation"117 is underpinned by a new approach in the psychological theories of the crowd, the Elaborated Social Identity Model (ESIM) developed first by Steve Reicher. ${ }^{118}$ PLTs clearly have considerable potential for maintaining public order, not for stemming trouble but for averting it - "no surprises policing" - but also bring disguised strategic advantages. ${ }^{119}$ Most notably, activist groups have expressed concern about the use of PLOs as part of the State's data and intelligence gathering arm. There is evidence of former FIT officers (Forward Intelligence Team) retraining and being redeployed as PLOs, and indeed evidence from the police themselves of such use. Netpol reports how Chief Inspector Sonia Davis, head of the Police Liaison Teams (PLT) unit in the Metropolitan Police, gave evidence as a prosecution witness in the trial of Critical Mass cyclists arrested on

\footnotetext{
115 There is also evidence of another of his models, the Miami model - depicted as excessive force in controlling and dispersing protesters: see e.g. Gilmore, Jackson and Monk Keep Moving! Report on the Policing of the Barton Moss Community Protection Camp, November 2013-April 2014 (2016) 26-29 available here http://eprints.whiterose.ac.uk/115146/

116 (1991) 13 EHRR 204.

${ }^{117} \mathrm{H}$ Gorringe et al "Facilitating ineffective protest? The policing of the 2009 Edinburgh NATO protests" (2012) 22 Policing and Society 115, 129.

${ }^{118} \mathrm{~S}$ Reicher "The Battle of Westminster: Developing the Social Identity Model of Crowd Behaviour in Order to Explain the Initiation and Development of Collective Conflict" (1996) 26 European Journal of Social Psychology 115.

${ }^{119}$ See generally C Stott, M Scothern and H Gorringe "Advances in Liaison Based Public Order Policing in England: Human Rights and Negotiating the Management of Protest?" (2013) 7 Policing 212 and more critically J Gilmore, W Jackson and H Monk "That is not facilitating peaceful protest. That is dismantling the protest': anti-fracking protesters' experiences of dialogue policing and mass arrest" (2017) Policing and Society forthcoming, prepublication copy here http://dx.doi.org/10.1080/10439463.2017.1319365
} 
the evening of the Olympics opening ceremony. Under cross-examination, Davis admitted that PLTs gather information on protesters and had even been covertly deployed at previous Critical Mass rides to try to identify 'leaders'. ${ }^{120}$ This is alongside the PLO's standard operating procedures which confirms they are "likely to generate high-quality intelligence from the discussions they are having with [protest] group members". ${ }^{121}$

\section{Private Regulation}

The third significant change over the past decade or so has been the increased role played by what I have termed "privatised regulation", where control is no longer in the hands of the state through arrest and prosecution, or through the exercise of administrative discretion in the POA $1986 .{ }^{122}$ It is now well documented that private companies - actual or potential targets of protesters - undertake surveillance of activist groups by using corporate intelligences firms. In late 2017, The Guardian and The Bureau of Investigative Journalism reported that leaked documents revealed British Airways, the Royal Bank of Scotland and Porsche among five large companies identified as having paid corporate intelligence firms to monitor political groups that challenged their businesses. ${ }^{123}$ Egregious as that is, that is not the limit to corporate

\footnotetext{
${ }^{120}$ Netpol “Police Liaison Officers” https://netpol.org/police-liaison-officers/ (access on 19 December 2017). ${ }^{121} \mathrm{Ibid}$

${ }^{122}$ D Mead "A Chill Through the Back Door? Privatised Regulation of Peaceful Protest" [2013] PL 98.

${ }^{123} \mathrm{R}$ Evans and M Jones "Surveillance firms spied on campaign groups for big companies, leak shows" The Guardian 12 December 2017 https://www.theguardian.com/world/2017/dec/12/surveillance-firms-spied-on-campaign-groups-for-bigcompanies-leak-shows (access on 19 December 2017). See too this from Ireland in 2012: L Siggins "Rossport protesters under 24-hour surveillance by private security firm" The Irish Times 10 August 2012 https://www.irishtimes.com/news/rossport-protesters-under-24-hour-surveillance-by-private-security-firm1.533819 (access on 19 December 2017).
} 
regulation of protest. We shall look at two, the continued reliance on private law remedies and the appearance of what has been termed 'pay to protest'.

Where the case reports once comprised injunctions granted in favour of Huntingdon Life Sciences, restraining animal rights activists, they now feature claims brought by fracking companies against environmental protesters. While many of these are civil claims for repossession of land - evicting protesters from a camp - some have been aimed at the form of action, rather than its location (accepting of course the blur between those two $\left.{ }^{124}\right)$. In September 2017, injunctions against "persons unkown" obtained by INEOS - a multinational petrochemical company - were challenged by two campaigners on the grounds they were overly broad, and thus overly restrictive of free speech and protest, and created too great a chill. ${ }^{125}$ They did not succeed. ${ }^{126}$ One characteristic of privatised regulation, and this INEOS injunction is no different, is that it exposes protesters to prison, for contempt, for conduct that would not otherwise lead to arrest and prosecution. The INEOS injunction for example banned the obstruction of free passage along a highway with the intention of obstructing, impeding or interfering with the lawful activities of the company or its agents, ${ }^{127}$ of potentially wider scope than the offence of wilful and unreasonable obstruction of the highway contrary to s.137 of

\footnotetext{
${ }^{124}$ Tabernacle v Ministry of Defence [2009] EWCA Civ 23.

${ }^{125} \mathrm{R}$ Evans "Campaigners challenge injunction against anti-fracking protesters" The Guardian 12 September 2017 https://www.theguardian.com/environment/2017/sep/12/anti-fracking-campaigners-challenge-ineosinjunction-joe-corre-joe-boyd (access on 19 December 2017).

${ }^{126}$ [2017] EWHC 2945 (Ch).

127 Ineos-shale "Injunction" 23 November 2017 https://www.ineos.com/businesses/ineos-shale/injunction/ (access on 19 December 2017).
} 
the Highways Act 1980. There is also evidence that the chill goes wider than simply affecting actual or potential protesters. Some are drawn so broadly that they could conceivably capture those who offer support food, water or medicine - for anyone protesting and, in the case of one, prevent legitimate reporting by restraining "persons unknown who intend to enter and/or to remain on the site in connection with the protest". ${ }^{128}$ Whether these injunctions do properly restrict journalists is not the point; if they fear that they might do so, the chill is there.

Another characteristic of certain types of injunction - those that restrain protests outside or near places of business - is that it privatises the control of public space. We see this with the INEOS injunction, but also with this one, granted in favour of Harvey Nichols against animal rights activists, protesting the shop's return to selling fur. ${ }^{129}$ By creating exclusion zones around the entrances to the seven stores across the UK, an otherwise perfectly lawful activity - simply being together on the pavement - is rendered subject to control, and incursions subject to penalty. The further ban on megaphones illustrates yet further the regulation - and criminalisation for violation - of otherwise lawful activity, that of being loud in public. Other SLAPP claims include "standard" ones for defamation, based usually on assertions made by activists and campaigners in a public forum of some sort. In May 2017, UK Oil and Gas Investments plc sent pre-action protocol letters to various members of

\footnotetext{
128 Injunction in favour of oil/gas company in relation to land in south England, obtained in confidence. Copy with the author.

129 Williamsons Solicitors "Harvey Nics wins anti-fur injunction" 9th December 2014

http://www.mrw-law.co.uk/news/2014/12/09/harvey-nichols-wins-anti-fur-protests-injunction/ (access on 19 December 2017).
} 
Keep Billingshurst Frack Free following comments made in the group's newsletter including the sentence suggesting the planned works were completely ill-judged and "presumably the company thinks it can bully the regulators into giving them permission". ${ }^{130}$

There is another aspect to the increasing relevance of private (law) modes of control and repression that has reared its head in the past few years This is what has become known as "pay to protest". In short, the police indicate in advance that they are unable or unwilling to provide a sufficient presence as to ensure the safety of protesters. If the organisers wish to proceed, they are told they must fund their own security. In February 2015 , climate change protesters were told to hire a private firm to oversee a march - after the police indicated they would no longer facilitate the temporary closure of roads along the agreed route. The group, The Campaign Against Climate Change estimated the bill could run into thousands of pounds. ${ }^{131}$ This was not a one-off. At the same time, the Million Women March was told the same. ${ }^{132}$ Numbers are not known, and inevitably there will be groups that if told they will have to pay, will decide not to march or demonstrate. Litigation here is extremely unlikely, as are these policing decisions making the news, so it will all remain under the radar. In the end, public pressure and campaigning by Liberty reversed the

\footnotetext{
${ }^{130}$ Copy of solicitors' letter seen by the author and on file.

131 J Doward "Climate change marchers told to hire private security firm" The Guardian 7 February 2015 https://www.theguardian.com/world/2015/feb/07/climate-change-marchers-private-security-protestpolice (access on 19 December 2017).

${ }^{132} \mathrm{R}$ Evans "Met police 'pay to protest' proposal rejected by campaigners" The Guardian 19 February 2015 https://www.theguardian.com/world/2015/feb/19/met-polices-pay-to-protest-proposal-rejected-bycampaigners (access on 19 December 2017). See too a planned homelessness protest in Chelmsford in 2016: Liberty press release "Liberty: Essex Police must allow homelessness protest" 18 February 2016 https://www.liberty-human-rights.org.uk/news/press-releases-and-statements/liberty-essex-police-mustallow-homelessness-protest (access on 19 December 2017).
} 
decision in the scenario in point: Westminster City Council and Transport for London ( $\mathrm{TfL}$ ) confirmed they would arrange road closures to allow the climate change march to go ahead. ${ }^{133}$ I have discussed elsewhere some of the theoretical problems for human rights law that are thrown up by the imposition of a duty on organisers to pay to protest. ${ }^{134}$ Specifically, it removes the universality of the right - exercisable in such circumstances only by those who can afford to pay, not by all - and asks us to reconceptualise it as something based not on public and social utility - a right with a justifiable claim to instrumentality - but one founded on its intrinsic worth only to those individual participants. Such a reconfiguring, where rights project only private value, runs the risk of the right losing out in practical terms at the balancing stage, when the public interest is inveighed against it. ${ }^{135}$

\section{Access to Place and Space}

The last focus of this article is on the interplay between protest and place, a very fruitful topic for exploration. We considered above the changes to the regulatory regime around Parliament, and more widely by

\footnotetext{
133 Liberty press release "Victory for campaigners as "pay to protest" authorities back down" 26 February 2015

https://www.liberty-human-rights.org.uk/news/press-releases/victory-campaigners-\%E2\%80\%9Cpayprotest\%E2\%80\%9D-authorities-back-down (access on 19 December 2017). It may not be policing or security for which payment is being required; it could extend to more than de minimis licensing charges for a street theatre protest: see Mead n24, 117 and Netpol "Resisting the police's new 'pay-to-protest' policy" 11 February 2015 https://netpol.org/2015/02/11/pay-to-protest/ (access on 19 December 2017).

${ }^{134} \mathrm{D}$ Mead "Quis debiet ipsos custodes? The real costs of the cost of protest" ProtestMatters blog 11 February 2015 https://protestmatters.wordpress.com/2015/02/11/quis-debit-ipsos-custodes-the-realcosts-of-the-cost-of-protest/ (access on 19 December 2017).

135 On this, in the context of media intrusions, see D Mead "A Socialised Conceptualisation of Individual Informational Privacy: A Theoretical and Empirical Study" (2017) J Media Law 100, 130.
} 
PSPOs, but here we will consider the position of the Occupy movement that sprung up worldwide, in response to the austerity measures imposed to deal with the global financial crisis, such as Zuccotti Park in New York and Puerto del Sol in Madrid, as well as restrictions on civic space more generally.

In the UK, the various occupations generated much case law, none of it successful from the protesters' perspective. All, broadly, followed the same jurisprudential line - a recognition that the right to protest peacefully extended to occupations of land (that is, an occupation engages Article 11), but ultimately the protesters lost because the courts have taken the view that anything longer than a temporary incursion constitutes a disproportionate use. Thus the interference - the disbanding of the camp - was justified and necessary. The City of London authorities were granted a possession order by Lindblom J, confirmed by the Court of Appeal, in Samede in respect of the three-month long Occupy LSX camp outside St Paul's. ${ }^{136}$ Various factors countervailed the protesters' Art 11 rights. The protest was itself a trespass, one that substantially interfered with a public right of way and with the rights of those who wished to worship in the Cathedral. It was in breach of planning control, and was causing a strain on public health facilities, and some damage to local businesses. The Court of Appeal took pains to distinguish the instant facts from those in Tabernacle, a once monthly weekend camp outside Aldermaston nuclear facility. ${ }^{137}$ There, members of the public (and

\footnotetext{
${ }^{136}$ The Mayor Commonalty and Citizens of London v Samede [2012] EWHC 34 (QB) and [2012] EWCA Civ 160.

${ }^{137}$ Tabernacle n?
} 
therefore, at least prima facie the protesters) had the right to pitch tents where the protest was camped, and it was neither a permanent nor a continuous presence. Further, there was no interference with any thirdparty rights; the very object of their protest was on adjoining land owned by the same public landowner. Furthermore, the protest had continued for twenty years with no complaint. ${ }^{138}$ The Court of Appeal in Samede summarised the case law and position as follows:

while the protesters' Article 10 and 11 rights are undoubtedly engaged, it is very difficult to see how they could ever prevail against the will of the landowner, when they are continuously and exclusively occupying public land, breaching not just the owner's property rights and certain statutory provisions, but significantly interfering with the public and Convention rights of others, and causing other problems (connected with health, nuisance, and the like), particularly in circumstances where the occupation has already continued for months, and is likely to continue indefinitely. ${ }^{139}$

We see similar sentiments and outcomes in the Democracy Village case (on Parliament Square in London ${ }^{140}$ ), the Grow Heathrow litigation ${ }^{141}$, and the Scottish Indycamp case, outside the Holyrood Parliament ${ }^{142}$ and the clearing of the Olympics site in $2012 .{ }^{143}$ Most recently, it filters through

\footnotetext{
${ }^{138}$ Samede [2012] EWCA Civ 160 [44]-[45].

139 Ibid [49].

${ }^{140}$ Hall v Mayor of London [2010] EWCA Civ 817.

${ }^{141}$ Malik v Fassenfelt [2013] EWCA Civ 798, and S Laville "Grow Heathrow runway protest community given 14 days to leave site" The Guardian 29 June 2017 https://www.theguardian.com/environment/2017/jun/29/grow-heathrow-runway-protest-communitygiven-14-days-to-leave-site (access on 19 December 2017).

${ }^{142}$ Scottish Parliamentary Corporate Body v Sovereign Indigenous Peoples of Scotland (No.2) [2016] CSOH 113

${ }^{143}$ Olympic Delivery Authority v Persons Unknown [2012] EWHC 1012 (Ch).
} 
INEOS $v$ Persons Unknown, the anti-fracking injunction case decided in November 2017 that we touched on above. ${ }^{144}$

We might just note a few problems of a more conceptual nature that the judicial approach in cases such as these evinces. The first is that in general the courts divorce the manner and form of the protest - here the place - from its essence, though not always so. The conclusion that this is not then a restriction on protest per se then naturally follows. There is now a wide and varied literature (including the ethnographical) on the constitutive nature of place for protest. Activists might (temporarily) reconstruct place to make their point, such as the planting of trees in the tarmac of the M41 extension in Shepherd's Bush, in west London by Reclaim the Streets in 1996 to make evident the stark contrast between what was to come and what could have been, ${ }^{145}$ or might more actively become the site of direct and longer term resistance, such as the Pollok Free State during the extension of the M77 south of Glasgow in the mid 1990s. ${ }^{146}$ As geographer Tim Cresswell put it, "the qualities of place that make them good strategic tools of power simultaneously make them ripe for resistance in highly visible and often outrageous ways." ${ }^{147}$ Tabernacle is one where the court did not take that analytical route. ${ }^{148}$ Secondly, we should treat with caution assumptions that prioritise the public highway as a place for passage, and perhaps as a place for commerce, what

\footnotetext{
144 [2017] EWHC 2945 (Ch).

${ }^{145}$ http://www.bernieduffy.com/2016/07/05/west-cross-route-to-the-world/ access on 10 January 2018. ${ }^{146}$ See e.g. P Routledge "Make Some Space: Camps, Commons and Occupations" in Space Invaders (Pluto Press 2017) chap 3.

${ }^{147}$ T Cresswell In Place/Out of Place: Geography, Ideology and Transgression (University of Minnesota Press, 1996), 164.

${ }^{148}$ Tabernacle n? [35]-[38].
} 
Nicholas Blomley typifies as traffic logic, than as a place equally for civic participation and as sites of mutually contested expression. ${ }^{149}$ Thirdly, the cases - though no doubt a function of how the protesters' cases are argued - underplay the organisational and mobilisational capacity that protest camps and occupations afford. ${ }^{150}$ The Carpenter's Estate in Newham was cleared for redevelopment (as part of the council's postOlympics plans) but had lain empty. It was taken over by a group of single mothers (Focus E15) who had all been living in council hostels but were threatened with dispersal across the UK when Newham decided to close them as part of its post-2008 austerity package. The occupation was thus a form of resistance - to the group's relocation - but also served to highlight the pan-London growth of gentrification. The occupation kickstarted wider activism by offering the opportunity for publicity and social engagement: "The occupied flats were opened to the public and ran as a social centre for two weeks, with an evolving program of daily events, including workshops, meetings, and music and comedy gigs." ${ }^{151}$ We might think of them as what Paul Routledge termed "convergence spaces", creating heterogeneous affinity between various social formation ${ }^{152}$, exposing participants to new, and different, ways of "doing politics", such as the bottom-up Peoples' Assembly at St Pauls. Lastly, the cases can be read as presuming that which evidently is not the case: the ready and free

\footnotetext{
${ }^{149}$ N Blomley "Civil Rights Meet Civil Engineering: Urban Public Space and Traffic Logic" (2007) 22 Canadian Journal of Law and Society 55 and Rights of Passage: Sidewalks and the Regulation of Public Flow (Routledge, 2011).

${ }^{150}$ On camps generally see C Hailey Camps: A Guide to $21^{\text {st }}$ Century Space (MIT Press, 2009) where protest camps feature in the third of his typologies: camps of necessity, camps of control and camps of autonomy. More specifically see A Feigenbaum, F Frenzel and P McCurdy Protest Camps (Zed Books, 2013).

${ }^{151}$ FocusE15 website https://focuse15.org/about/

152 P Routledge "Convergence space: process geographies of grassroots globalization networks" (2003) 28(3) Transactions of the Institute of British Geographers 333.
} 
availability of public land, not something that it is in diminishing supply, its scarcity rendering it yet more politically valuable. Indeed, many of the occupations contested that very fact. The transfer of land into private hands, for development, is one of the more significant, but less remarked upon, narratives of Western political discourse over the past couple of decades, perhaps none more so than in the UK. In February 2016, the author Will Self warned that the spiritual wellbeing of cities was being eroded by the creeping corporatisation and privatisation of its public spaces. ${ }^{153}$ The danger is not simply that the spaces are no longer public, but that they falsely offer the solace of being public - through design and feel. ${ }^{154}$

Let us develop that point about diminution, by reflecting on civic space more widely a little more. While it is true that the UK has not been hit with the introduction of the sorts of law to have afflicted protesters and activists in Russia and India, to name but two - restrictions on NGOs and campaigning groups that receive foreign funding - we should be concerned at how the Transparency of Lobbying, Non-Party Campaigning and Trade Union Administration Act 2014 plays out. This imposes significant restrictions on what can be spent in an election period by nonparties, that is by groups who do not formally register with the Electoral Commission as a party under the Political Parties, Elections and Referendums Act 2000. The annual UK-wide campaign limits were cut to

\footnotetext{
${ }^{153} \mathrm{M}$ Townshend "Will Self joins London 'mass trespass' over privatisation of public space" The Guardian 13 February 2016 https://www.theguardian.com/uk-news/2016/feb/13/will-self-mass-trespass-londonprotest (access on 19 December 2017).

154 J Shenker "Corbyn joins calls to reclaim UK pseudo-public space from corporate owners" The Guardian 25 July 2017 https://www.theguardian.com/cities/2017/jul/25/corbyn-joins-calls-reclaim-uk-public-spacefrom-corporate-owners (access on 19 December 2017).
} 
about $45 \%$ of their pre-2014 amounts, from $£ 988,500$ to $£ 450,000 .{ }^{155}$ Serious concerns were raised during the Bill's passage about the affect on NGOs given the scope of the changed meaning of controlled expenditure in s.26(2)(b) and s.26(4)(c) of the 2014 Act: can it reasonably be regarded as intended to promote or procure electoral success at any relevant election of a party or candidate whether or not the conduct involves any express mention being made of the name of any party or candidate? That would, I would submit obviously, effect many political campaigning groups. Those worries were amplified in the absence of any evidence or data from the Government showing why the reductions were needed or what the effect might be of that changed definition of controlled expenditure. The Electoral Commission reported that in the 2005 elections, only 24 third-parties reported any spending and none came close to the then maximum. In 2010, not a single third-party spent more than $70 \%$ of the statutory limit. In each of 2005 and 2010, only two third-parties exceeded what would be that new lower limit. ${ }^{156}$ There must therefore be question marks as to the proportionality of the new framework, given the arbitrary, evidence-free rationales. As the Political and Constitutional Reform Committee put it during passage of the Bill:

We have stated already that we have not seen adequate evidence for setting the new thresholds for expenditure at the levels imposed by Part 2 of the Bill. The Government must explain the reasoning behind its decisions during the passage of

\footnotetext{
${ }^{155}$ There were variations across the regions: from $£ 793,500$ in England to $£ 319,800$, from $£ 108,000$ in Scotland to $f 55,400$, from $£ 60,000$ in Wales to $£ 44,000$ in Wales, and from $£ 27,000$ in Northern Ireland to $£ 30,800$

${ }^{156}$ House of Commons Political and Constitutional Reform Committee $7^{\text {th }}$ Report of session 2013/14 "The Government's lobbying Bill - Volume I" HC 601-I, 19 September 2013, para 66
} 
the Bill. Even if the Government can make the case for imposing lower levels, it must be able to give a convincing account of why it has chosen these particular limits as opposed to any others. If it cannot do so, we recommend that the existing levels continue to apply until such point as the case for change has been made. ${ }^{157}$

It must remain a worry that the Act will capture ordinary legitimate campaigning activities - or, as bad, that it will chill such activities, with groups erring on the side of caution. Alternatively, they might follow the line taken by Greenpeace, fined $£ 30,000$ for refusing to register as a "third-party campaigning organisation" in the run-up to the 2015 election. ${ }^{158}$ It will disproportionately disfavour campaigning on single issues where there is already a single-issue group such as, in recent times, the recently formed NHA party in the UK (since it captures the expenditure of groups aiming to persuade us to think favourably about topic $X$ and thus about policy $X$ and thus about party $X)$. The risk is certainly greater for policy-only campaigning groups. The Government's case was clear: it was important to get the big money out of politics, to prevent unregulated spending by vested interests having an undue influence on the outcome of elections. This required the threshold to be brought down, and disaggregated so it could not be spent disproportionately in small areas. Of course, there is an argument that the

\footnotetext{
157 Ibid, para 82.

${ }^{158}$ M Taylor "Greenpeace fined under Lobbying Act in 'act of civil disobedience"” The Guardian 18 April 2017 https://www.theguardian.com/politics/2017/apr/18/greenpeace-first-organisation-fined-lobbying-act (access on 19 December 2017).
} 
reduced sums will have little effect on the autonomy of third party groups to campaign and to seek to persuade. The rules have no bite outside an election period and, in any event, so few of them have previously spent anywhere near the new maximum. That may be so, but then another point arises. The symbolic shift that this heralds - combined with the national party limit of nearly $f 20 m$ and (say) s.319 of the Communications Act 2003, the ban on political advertising - is a preference for formal parties as the route to political change, and the vehicle for civic engagement rather than informal participation, through campaigning, protest, activism and opposition. That marks a significant change in policy.

\section{CONCLUSION}

In 2016, the UN Special Rapporteur on the Rights to Freedom of Peaceful Assembly and of Association in his follow up report on the UK (three years after his first visit in 2013) noted his appreciation of the Government's efforts to address some of his earlier recommendations. However, he continued, he was concerned

that a series of separate measures by the Government, some implemented and others proposed, have negatively impacted the exercise of the rights to freedom of association and freedom of peaceful assembly, and in general, are resulting in the closing of space for civil society. In many instances, these moves have been subtle and gradual, but they are as unmistakable as they are alarming... [and was] concerned that, 
put together, these measures suggest that the Government has a negative view of civil society as a critical partner that can and should hold it accountable. ${ }^{159}$

This article has identified and tracked many of these. Of course, we should acknowledge the many, many successful protests that occur in the UK every year, whether large-scale and organised or an ad hoc action comprising just a handful. ${ }^{160}$ These have not been our concern, though they perhaps should have been: that many of us can enjoy undisturbed political participation tells us much. Law's focus though is usually on the problematic, the contentious and the difficult. Of this, there is much, as we have seen. The UK is not alone in taking a more regressive path. The International Centre of Not-for-profit Law has created a US Protest Law Tracker, following initiatives at state and federal level since the election of President Trump in November 2016 that restrict the right to protest. ${ }^{161}$ So far (as at the end of November 2017) 27 states have considered 48 bills. Eight have been enacted, with 25 pending and 15 defeated. These include mandatory one-year suspensions for any student who is twice "found responsible for infringing on the expressive rights of others," such as through a protest of a campus speaker (Illinois), empowering police to use "any means necessary" to break up public assemblies of ten or more that obstructed traffic (Indiana) and criminalising certain protest actions as economic terrorism (North Carolina). Globally, liberalising measures are harder to find.

\footnotetext{
${ }^{159}$ Report of the Special Rapporteur on the rights to freedom of peaceful of association on his follow-up mission to the United Kingdom of Great Britain and Northern Ireland (Human Rights Council, $35^{\text {th }}$ session, 623 June 2017 A/HRC/35/28/Add.1)

160 Whether or not they are successful at effecting political change or in ways of thinking is beyond the confines of this article.

${ }^{161} \mathrm{http} / / /$ www.icnl.org/usprotestlawtracker/
} 
Perhaps that expansion of legal regulation, and consequent diminishing of political space, has contributed to an expansion in forms of innovative transgression. ${ }^{162}$ We might think of the Take a Knee protest, which originated in the NFL in the USA - kneeling during the National Anthem in protest at the treatment of fellow black citizens - and which has spread to European football (members of German team Hertha Berlin did so at a home game in October ${ }^{163}$ ) and the world of entertainment ${ }^{164}$ and been taken up by US army veterans. ${ }^{165}$ In Poland in 2016, opposition to the country's abortion law was signified by a forest of coat hangers suspended from wires outside Parliament ${ }^{166}$, while in Paris, at the time of COP21 in November 2015, there was a state of emergency - following the Bataclan terrorist attack in the city a few days previously. This meant a city-wide ban on assemblies. This was no hindrance to those seeking to show their opposition to governmental inaction on climate change: rows and rows of shoes were left. ${ }^{167}$ At its height, La Place de la Republique was decked with over 20,000 pairs. ${ }^{168}$ Likewise, Spain in April 2015,

\footnotetext{
${ }^{162}$ D McAdam, S Tarrow, and C Tilly Dynamics of Contention (Cambridge University Press, 2001), 7-8 ${ }^{163}$ BBC news 14 October 2017, http://www.bbc.co.uk/sport/football/41623019 (access on 15 January 2018).

${ }^{164}$ B Beaumont-Thomas "Pharrell Williams 'takes a knee' in Charlottesville protest "” The Guardian 25 September 2017 https://www.theguardian.com/music/2017/sep/25/pharrell-williams-take-a-kneecharlottesville-protest-nfl-donald-trump (access on 19 December 2017).

${ }^{165}$ CBS News "Sacramento vets take a knee to protest injustice at city council meeting" 4 October 2017 https://www.cbsnews.com/news/sacramento-vets-take-knee-protest-injustice-city-council-meeting/ (access 15 January 2015).

${ }^{166}$ NBC news 26 April 2016, "Abortion in Europe: 'Coat Hanger Rebellion' Grips Poland" https://www.nbcnews.com/storyline/europes-abortion-fight/abortion-europe-coat-hanger-rebellion-gripspoland-n559621 (access on 15 January 2018).

167 Indeed, thinking more reflexively, this might be another example of how the regulation of place creates a political response, as we saw with Mark Thomas earlier.

${ }^{168}$ CBC news 29 November 2015 "Shoes stand in silent protest at Paris climate conference" http://www.cbc.ca/news/world/climate-protest-paris-1.3342384 (access on 19 December 2017).
} 
following the passing of very restrictive laws banning protests in the vicinity of parliament, witnessed the world's first hologram protest. ${ }^{169}$

What is also clear have been the opportunities - or "affordances"170 that technology and social media now offer. One remarkable development over the past decade or so has been the explosion in on-line campaigning, through Facebook and Twitter hashtags such as \#BlackLivesMatter and more recently \#MeToo, in light of the sexual abuse scandals to have hit the entertainment industry and politics in 2017. In the UK, Stop Funding Hate formed as an on-line presence in the summer of 2016 "when a group of people came together online to express concern at the way certain newspapers were using hate and division to drive sales." ${ }^{171}$ The group's aim is to facilitate concerted public pressure as a means to persuade companies to cease taking out adverts in newspapers like The Daily Mail, The Express and The Sun. In late November, the stationery group Paperchase offered the following public apology for its Christmas wrapping paper promotion in The Daily Mair ${ }^{72}$ :

\footnotetext{
${ }^{169}$ Z D Boren "Spain's hologram protest: Thousands join virtual march in Madrid against new gag law" The Independent 12 April 2015 http://www.independent.co.uk/news/world/europe/spains-hologram-protestthousands-join-virtual-march-in-madrid-against-new-gag-law-10170650.html (access on 19 December 2017).

${ }^{170}$ On which see B Cammaerts "Technologies of self-mediation: affordances and constraints of social media for protest movements" in J Uldam and A Vestergaard (eds.) Civic Engagement and Social Media: Political Participation Beyond Protest (Palgrave Macmillan, 2015).

${ }^{171}$ The group's webpage is https://stopfundinghate.org.uk/about-the-campaign/campaign-history/ (access on 7 December 2017).

$172 @$ @romPaperchase tweet 09:28, 20 November 2017 https://twitter.com/FromPaperchase (access on 19 December 2017).
} 
Paperchase

(isFromPaperches

We've listened to you about this weekend's newspaper promotion. We now know we were wrong to do this - we're truly sorry and we won't ever do it again. Thanks for telling us what you really think and we apologise if we have let you down on this one. Lesson learnt.

9.28 AM - Nov 20, 2017

Social media also offers campaigners ample amplification. In the run-up to the General Election in 2017, Captain Ska released "Liar Liar", including several clips of Theresa May's speeches, with the chorus: "She's a liar, liar, oh, she's a liar. No you can't trust her, no, no, no." It received no airplay a result of regulatory impartiality guidelines but reached No1 in both Amazon's listing for songs downloaded in Britain and the iTunes UK chart - prompting considerable media interest and exposure. As of early December 2017, it had been viewed over 3m times on YouTube. The capacity for on-line organisation and opposition should not be underplayed. In January 2018, the appointment of journalist/commentator and Free School founder Toby Young, to the Board of the new university regulator (the Office for Students) was surrounded in controversy, given many of his earlier expressed views (in social media and in print) on such matters as eugenics, disability and women. This in turn led to a Twitter campaign and on-line petition through Change.Org that garnered over 220,000 signatures in a handful of days. ${ }^{173} \mathrm{He}$ resigned after just a week in post.

\footnotetext{
${ }^{173}$ https://www.change.org/p/theresa-may-mp-sack-toby-young-from-university-watchdog-post (access 15 January 2018).
} 
Over the past decade, public support for the right to protest - that is, to hold demonstrations and marches - has remained stable. The latest British Social Attitudes Survey 2017 shows 87\% support for organising public meetings to protest against the government and $73 \%$ support for organising protest marches and demonstrations. ${ }^{174}$ Indeed, and remarkably, there has been an increase in support for those with extremist views having such rights: $50 \%$ (46\% in 2006) saying those who want to overthrow the government by revolution should "definitely" or "probably" be allowed to hold public meetings to express their views, while $53 \%$ (50\% in 2006) hold the view that those who want to overthrow the government by revolution should "definitely" or "probably" be able to publish books expressing their views. This perhaps is the prism through which we should view the 2010 Coalition pledge to "restore rights to non-violent protest", ${ }^{175}$ designed to secure a little more protection for the mass, staged outpourings of grievances for resolution within and by that political system. The BSA data tells us nothing about public support for disruptive or obstructive, and more confrontational, forms of political activism. Such protests have become far more the mainstay in the UK over the past several years, especially - but not exclusively - as a means to oppose the expansion of fracking operations. It is high time for a national conversation focussing on the law and such forms of resistance. Furthermore, we can see why - however widely drawn it was drawn, and however peaceful the protesting activities it sought to protect - the 2010 pledge was doomed to fail. The problem is not, and rarely is, "the law".

\footnotetext{
${ }^{174}$ E Clery and D Mead British Social Attitudes 34: Civil Liberties p.10-12 up from 86\% and down from $77 \%$ in 2006 respectively. The report is available here http://www.bsa.natcen.ac.uk/latest-report/british-socialattitudes-34/civil-liberties.aspx

${ }^{175}$ Above n2.
} 
Two examples make this clear. In November, The Guardian reported that the Police Investigations and Review Commissioner (PIRC), which oversees police conduct in Scotland, upheld three complaints from the Scottish Palestine Solidarity Campaign (SPSC) after officers in Aberdeen visited one man at home to warn him off attending a rally, barred activists from entering a court and used an activists' meeting to gather intelligence. The PIRC suggested that this risked breaching the activists' human rights by interfering with their rights to peaceful protest and to privacy. ${ }^{176}$ Secondly, a recent report by Netpol 'Protecting the Planet is Not a Crime' highlighted the aggressive, zero-tolerance policing tactics towards any form of disruption - for example the tactic of "slow-walking"177 -adding that this not only criminalised large numbers of people, but backfired, escalating further civil disobedience rather than reducing it. Without attending to those structural imbalances of power between citizen and police, and between state and activist, and to those judicial assumptions of legitimacy and of the role of activism within a democracy - inherent in many judgments we considered - any proposed reforms will do no more than tinker at the edges.

\footnotetext{
${ }^{176} \mathrm{~S}$ Carrell "Scottish police thwarted Palestinian activists' right to protest in peace "” The Guardian 13 November 2017 https://www.theguardian.com/world/2017/nov/13/scottish-police-thwarted-palestinianactivists-right-to-protest-in-peace (access on 19 December 2017).

177 The report is available here https://netpol.org/2017/11/20/report-launch-north-yorkshire/ p.7-8
} 
